\title{
Familial chondrocalcinosis in the Chiloe Islands, Chile
}

\author{
ANTONIO J. REGINATO, JOSEPH L. HOLLANDER, VIRGINIA MARTINEZ, \\ FER NANDO VALENZUELA, VIRGILIO SCHIAPACHASSE, EDMUNDO \\ COVARRUBIAS, SERGIO JACOBELLI, ROBERTO ARINOVICHE, DONALD \\ SILCOX, AND FRANCISCA RUIZ \\ From the Arthritis Section, San Juan de Dios Hospital, Santiago, Chile; University of Chile, National Health \\ Service; Arthritis Section, Hospital of the University of Pennsylvania, Philadelphia, Pa.; and Department of \\ Cellular Biology and Genetics, University of Chile
}

\begin{abstract}
Reginato, A. J., Hollander, J. L., Martinez, V., Valenzuela, F., Schiapachasse, V., Covarrubias, E., Jacobelli, S., Arinoviche, R., Silcox, D., and Ruiz, F. (1975). Annals of the Rheumatic Diseases, 34, 260-268. Familial chondrocalcinosis in the Chiloe Islands, Chile. Studies about chondrocalcinosis in the Chiloe Islands (Chile) showed the high frequency of the disease there and how most of it is aggregated in a few highly involved families. Pedigrees and the high degree of consanguinity among parents of index cases pointed to a recessive inheritance. The presence of common Caucasian anthropological features of genetic value in the patients and the lack of Indian mixture in three of the involved families, documented back to 1600 , suggest a Caucasian origin of the mutation.

Biochemical studies of the patients' synovial fluid showed a significant rise in pyrophosphate concentration. Calcium, phosphorus, and alkaline phosphatase concentrations were not different from a control group.
\end{abstract}

The hereditary features of primary chondrocalcinosis were described by Valsick, Zitnan, and Sit'aj (1963). They published a study of 35 cases with polyarticular chondrocalcinosis, 24 of which were members of five families and 26 from one locality in Czechoslovakia. They postulated the existence of two phenotypes, one characterized by severe polyarticular involvement starting at a young age and a second oligosymptomatic form found in older people with calcifications in few joints. From their genetic data it was difficult to define unequivocally the pattern of autosomal inheritance (Valsik and Zitnan, 1966).

In our series of 72 patients with articular chondrocalcinosis from mainland Chile, there were nineteen patients aggregated within six families whose ancestors settled the Chiloe Islands in the 16th century (Reginato, Valenzuela, Martinez, and Passano, 1970). We have therefore carried out a study in the islands themselves.

This report summarizes our own findings. There is a high frequency of the disease among the islanders and most of it is aggregated in a few highly involved families. Pedigrees and the high degree of consanguinity among parents of index cases pointed to a recessive inheritance. The presence of common Caucasian anthropological features in the patients, and the lack of Indian mixture in three of the involved families documented back to 1600 , suggest a Caucasian origin of the mutation.

Biochemical studies of the patients' synovial fluid showed a significant rise in pyrophosphate concentration. Calcium, phosphorus, and alkaline phosphatase concentrations were not different when compared with a control group.

\section{Material and methods}

DISTRIBUTION OF JOINT DISEASES IN THE CHILOE ISLANDS

This study was performed in a group of people who came for medical examination to three of the largest cities of the $\frac{7}{0}$ islands (Castro, Chonchi, and Quellon) in response to a radio announcement requesting patients with rheumatic $N$ symptoms. We studied 208 persons, 98 males and 110 females, with ages ranging from 20 to 68 years (mean of 48 . years). All were born in the islands. Relatives of our $\mathrm{\omega}$ previously reported patients were excluded in order to show more representative results.

A complete clinical rheumatological evaluation was performed in each patient. Standard anteroposterior $\stackrel{\infty}{\rightleftharpoons}$ roentgenograms of knees and wrists were used as a screening test for chondrocalcinosis. Synovianalysis (Hollander, Reginato, and Torralba, 1966) and synovial $\underset{\mathbb{D}}{\stackrel{\odot}{ }}$ needle biopsy (Schumacher and Kulka, 1972) were done in $\cong$ pertinent cases. A blood sample was taken from each $\stackrel{\square}{\varrho}$ patient for the following determinations: serum latex 
fixation test for rheumatoid factor (Singer and Plotz, 1956), serum uric acid, calcium (Bachra, Dauer, and Sobel, 1958), phosphorus (Gomori, 1942), and alkaline phosphatase (Bodansky, 1932). A similar survey was performed in 48 relatives of the sixteen new cases of chondrocalcinosis found in this study.

In addition 1783 articular and spine films of patients of all ages, taken from the files of the radiology departments of the local hospitals, were reviewed for chondrocalcinosis.

Diagnostic criteria for chondrocalcinosis were: (a) identification of tri- or monoclinic weakly positive birefringent crystals in the synovial fluid or synovial membrane, and (b) characteristic radiodense deposits in the joint capsule, fibrocartilage, or articular cartilage. Patients with other joint diseases were classified according to special diagnostic criteria for population studies (Kellgren, Jeffrey, and Ball, 1963).

\section{FAMILY STUDIES}

Pedigrees were constructed for twelve families whose members were born in the Chiloe Islands, including our six previously reported families (Reginato and others, 1970). Information was obtained from each patient and relative studied, and later matched with the data obtained from the marriage book of the Catholic churches of the islands, dating from 1700 to 1973 (Catholic Parochial Church, 1700-1973), and from several publications on the genealogy of the first European families who settled there (Cavada, 1934; Gallardo, 1953; Mansilla, 1915; Vasquez de Acuna, 1959; Burr, 1902). Anteroposterior roentgenograms of knees and wrists, using a portable $x$-ray machine and ready-pack, nonscreen Kodak film, were performed on 400 relatives in order to investigate the presence of chondrocalcinosis (Parlee, Freundlich, and McCarty, 1967).

\section{ANTHROPOLOGICAL STUDIES AND BLOOD GROUPING}

A simple anthropological physical examination including eye and hair colour, presence of mesial palatal version, shovel-shape of the medial upper incisors, and blood grouping for ABO, MNS, Kell system, and Rh subgroups, were performed on 55 patients with chondrocalcinosis, and on 37 of their relatives. Blood grouping was performed by a test tube technique using commercially available reagents (Hyland, Costa Mesa, Calif.).

\section{DIETETIC AND MIGRATORY SURVEYS}

A qualitative dietetic canvass was performed on 45 patients (Weiner and Lourie, 1969), and the migrational survey on 55 patients (Fernandez, Covarrubias, Benado, Castelli, and Lamborot, 1966).

\section{BIOCHEMICAL STUDIES}

Noninflammatory synovial fluid supernates were tested for total calcium, phosphorus, and alkaline phosphatase in nine patients with familial chondrocalcinosis and in a control group of 24 patients with other joint diseases. The control group consisted of twelve cases of classical or definite rheumatoid arthritis, five cases of acute gouty arthritis, six cases of degenerative joint disease, and three consecutive samples from one patient with ochronotic arthropathy. Serum samples from 35 patients with chondrocalcinosis were also tested for calcium, phosphorus, alkaline phosphatase, uric acid, and serum latex fixation test for rheumatoid factor.

Pyrophosphate determination was performed on the noninflammatory synovial fluid of fifteen patients with familial chondrocalcinosis. Synovial fluid was collected in plastic syringes containing $0.2 \mathrm{ml}$ heparin and $0.2 \mathrm{ml}$ of a tracer of $\mathbf{P}^{32}$ (New England Nuclear Medicine, Boston, Mass.), immediately chilled in ice, and centrifuged at 5000 r.p.m. for 30 minutes. Samples were frozen and mailed in dry ice to Dr. D. J. McCarty's laboratory (University of Chicago). Pyrophosphate determination was performed by the method of Silcox and McCarty (1973).

\section{Results}

\section{FREQUENCY OF JOINT DISEASES IN THE} CHILOE ISLANDS

The results of this study are summarized in Table I. It can be appreciated from this table that out of 208 persons who came for examination, 31 were considered nonrheumatic. Fifty-two patients complained of arthralgias or had a history of one or two episodes of joint swelling, but at the time of this study they failed to exhibit clinical or radiological evidence of rheumatic disease. Sixty patients showed hand or knee degenerative joint disease, sixteen polyarticular chondrocalcinosis, and ten definite or classical rheumatoid arthritis. A similar clinical and radiological survey performed on 48 relatives of these sixteen patients with chondrocalcinosis disclosed calcifications of the intra-articular structures in eleven cases and classical rheumatoid arthritis in two cases.

The review of the articular and spine roentgenograms in 1783 patients taken from the files of the radiology departments showed chondrocalcinosis in nineteen cases.

Table I Distribution of rheumatic disease in 208 individuals born in the Chiloe Islands

\begin{tabular}{|c|c|c|}
\hline & $\begin{array}{l}\text { No. of } \\
\text { individuals }\end{array}$ & $\%$ \\
\hline $\begin{array}{l}\text { Nonrheumatic } \\
\text { Rheumatic } \\
\text { Arthralgias or intermittent joint } \\
\text { swelling } \\
\text { Degenerative joint disease } \\
\text { Chondrocalcinosis } \\
\text { Rheumatoid arthritis } \\
\text { Inactive rheumatic fever } \\
\text { Gout } \\
\text { Systemic lupus erythematosus } \\
\text { Traumatic arthropathy } \\
\text { Low back pain } \\
\text { Shoulder periarthritis } \\
\text { Miscellaneous }\end{array}$ & $\begin{array}{r}31 \\
177 \\
\\
52 \\
60 \\
16 \\
10 \\
7 \\
3 \\
3 \\
3 \\
10 \\
6 \\
7\end{array}$ & $\begin{array}{r}29.3 \\
33.9 \\
9.5 \\
5.6 \\
3.9 \\
1.6 \\
1.6 \\
1.6 \\
5.6 \\
3.3 \\
3.9\end{array}$ \\
\hline
\end{tabular}


The findings of 46 new cases of chondrocalcinosis in these studies confirmed the high frequency of this disease in the Chiloe Islands.

\section{CLINICAL AND RADIOLOGICAL FEATURES OF CHONDROCALCINOSIS IN PATIENTS BORN IN THE CHILOE ISLANDS}

As a result of these studies, we have found a total of 160 cases of chondrocalcinosis in patients born in the islands. Eighty of the best studied patients are summarized in Fig. 1, according to the age of onset of their articular complaints. Patients whose disease started early in life showed severe polyarticular chondrocalcinosis. They were incapacitated due to frequent pseudogout attacks associated with heavy, progressive intra-articular calcifications, degenerative changes, complete articular cartilage destruction, and even ankylosis in a few patients (Reginato and others, 1970). Most of the patients whose symptoms started after the fifth decade were oligosymptomatic and the calcium deposits were localized to the knee articular cartilage or menisci.

Eight patients showed areas of reabsorption of the subchondral bone along with calcification of the fibrocartilage of the symphysis pubis. Extra-articular

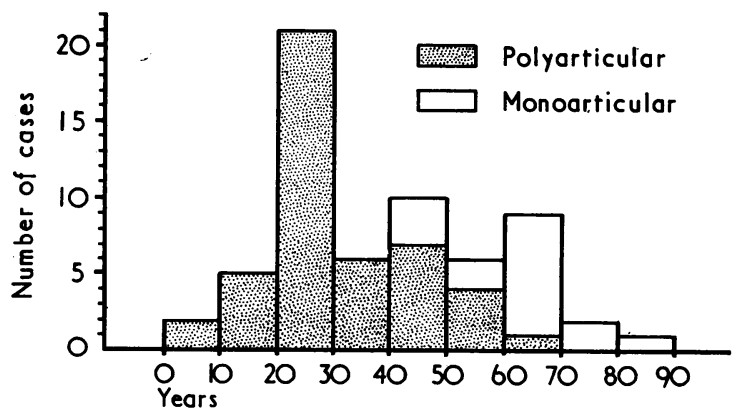

FIG. 1 Age of 80 patients (44 women, 36 men) with chondrocalcinosis. Age of onset of attacks of pseudogout in 62 cases. Ages range from 25-84 years (mean 54.5) calcifications were seen in the subdeltoid bursae and $\frac{\widetilde{\sigma}}{\widetilde{\sigma}}$ muscle insertion around the ischium in thirty patients. Roentgenograms of the ear cartilage performed in eight patients with severe chondrocalcinosis showed small areas of calcification in only $\Rightarrow$ two patients. These deposits were palpated and $\stackrel{5}{+}$ appeared to be deep in the cartilage. Needle aspiration? of these pseudotophi was not attempted.

\section{BIOCHEMICAL STUDIES}

Synovial fluid studies performed in patients with ڤँ chondrocalcinosis and a control group, including $\vec{\circ}$ different joint diseases, are summarized in Table II. Calcium, phosphorus, and alkaline phosphatase $\vec{\omega}$ activities did not show significant differences when compared with the control group. Pyrophosphate concentration in the synovial fluid was studied only $\omega$ in fifteen patients with chondrocalcinosis. Values $\dot{\omega}$ ranged from 3.4 to $18 \mu \mathrm{mol} / 1$ pyrophosphate with a i mean of $9.31 \pm 5.92 \mu \mathrm{mol} / 1$ pyrophosphate.

Serum calcium, phosphorus, and alkaline phos-을 phatase were within normal limits in 36 patients studied. Serum uric acid was raised in only four of $\bar{c}$ these patients, ranging from 0.39 to 0.46 , mean 0.42 ब $\mathrm{mmol} / \mathrm{l}(6.5$ to $7.8 \mathrm{mg} / 100 \mathrm{ml}$, mean $7 \cdot 05)$. The serum $\vec{\varphi}$ latex fixation test for rheumatoid factor was negatike ov in 35 patients in which this test was performed.

\section{FAMILY STUDIES}

We studied twelve families that had 57 members affected with chondrocalcinosis. Because of the $\frac{\circ}{\square}$ migrational tendency of the Chilotes, it was impossible $\stackrel{\varrho}{\rightarrow}$ to complete the pedigree in every family. Figs 2 and $3 \overrightarrow{ }$ contain the pedigrees of seven of the families that were studied more extensively. The other 24 patients with familial chondrocalcinosis were aggregated in five families. Many of these families shared identical surnames but complete retrospective information was not available and no link between them could be 3 shown.

There was a very high explicit consanguinity in $\frac{3}{3}$ these families studied. As most of the people belong

Table II Calcium, phosphorus, and alkaline phosphatase in the synovial fluid of 9 patients with chondrocalcinosis $\frac{7}{0}$ and 24 patients with other arthropathies

\begin{tabular}{|c|c|c|c|c|c|}
\hline & No. of patients & $\begin{array}{l}\text { Mean age } \\
\text { (years) }\end{array}$ & $\begin{array}{l}\text { Calcium } \\
(\mathrm{mmol} / \mathrm{l})\end{array}$ & $\begin{array}{l}\text { Phosphorus } \\
\text { (mmol/l) }\end{array}$ & $\begin{array}{l}\text { Alkaline } \\
\text { phosphatase } \\
B U\end{array}$ \\
\hline $\begin{array}{l}\text { Chondrocalcinosis } \\
\text { Ochronosis } \\
\text { Osteoarthritis } \\
\text { Gout } \\
\text { Rheumatoid arthritis }\end{array}$ & $\begin{array}{r}9 \\
1 \\
6 \\
5 \\
12\end{array}$ & $\begin{array}{l}50 \cdot 1 \\
65 \\
63 \\
56 \cdot 7 \\
50 \cdot 1\end{array}$ & $\begin{array}{l}1.94 \pm 0.19 \\
1.80 \pm 0.05 \\
1.99 \pm 0.16 \\
1.94 \pm 0.16 \\
2.07 \pm 0.25\end{array}$ & $\begin{array}{l}1 \cdot 14 \pm 0.3 \\
1.03 \pm 0.16 \\
1 \cdot 23 \pm 0.18 \\
1.05 \pm 0.16 \\
1 \cdot 15 \pm 0.20\end{array}$ & $\begin{array}{l}1 \cdot 15 \pm 0.95 \\
1 \cdot 3 \pm 0.22 \\
0.97 \pm 1 \cdot 26 \\
1 \cdot 18 \pm 0.76 \\
1 \cdot 36 \pm 0.95\end{array}$ \\
\hline
\end{tabular}




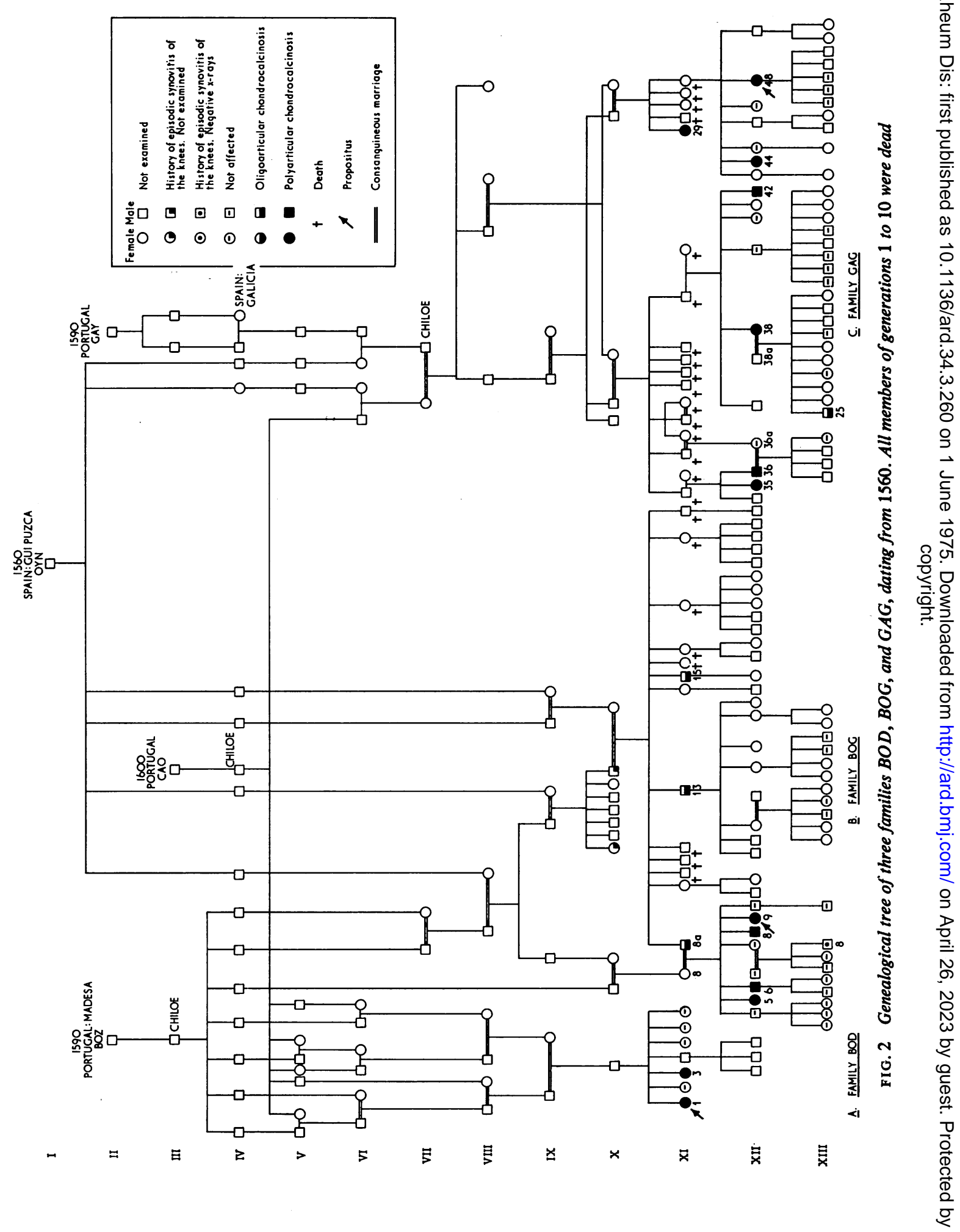



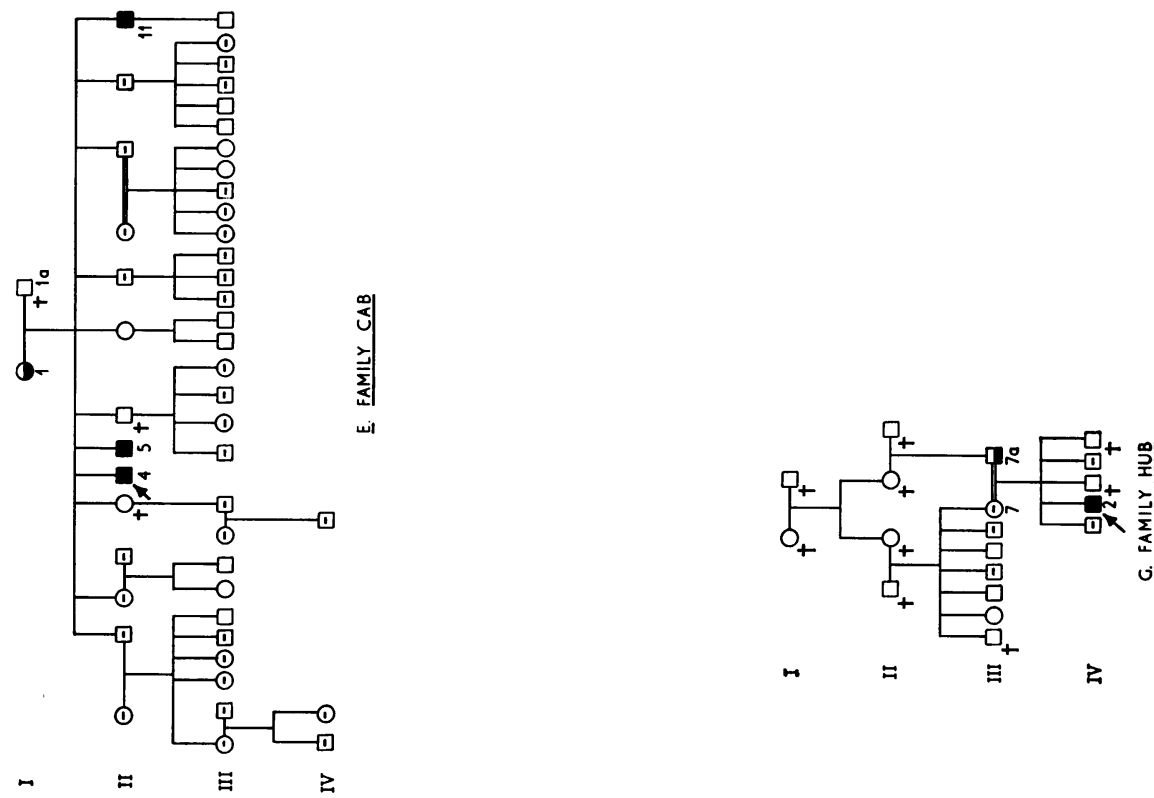

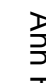
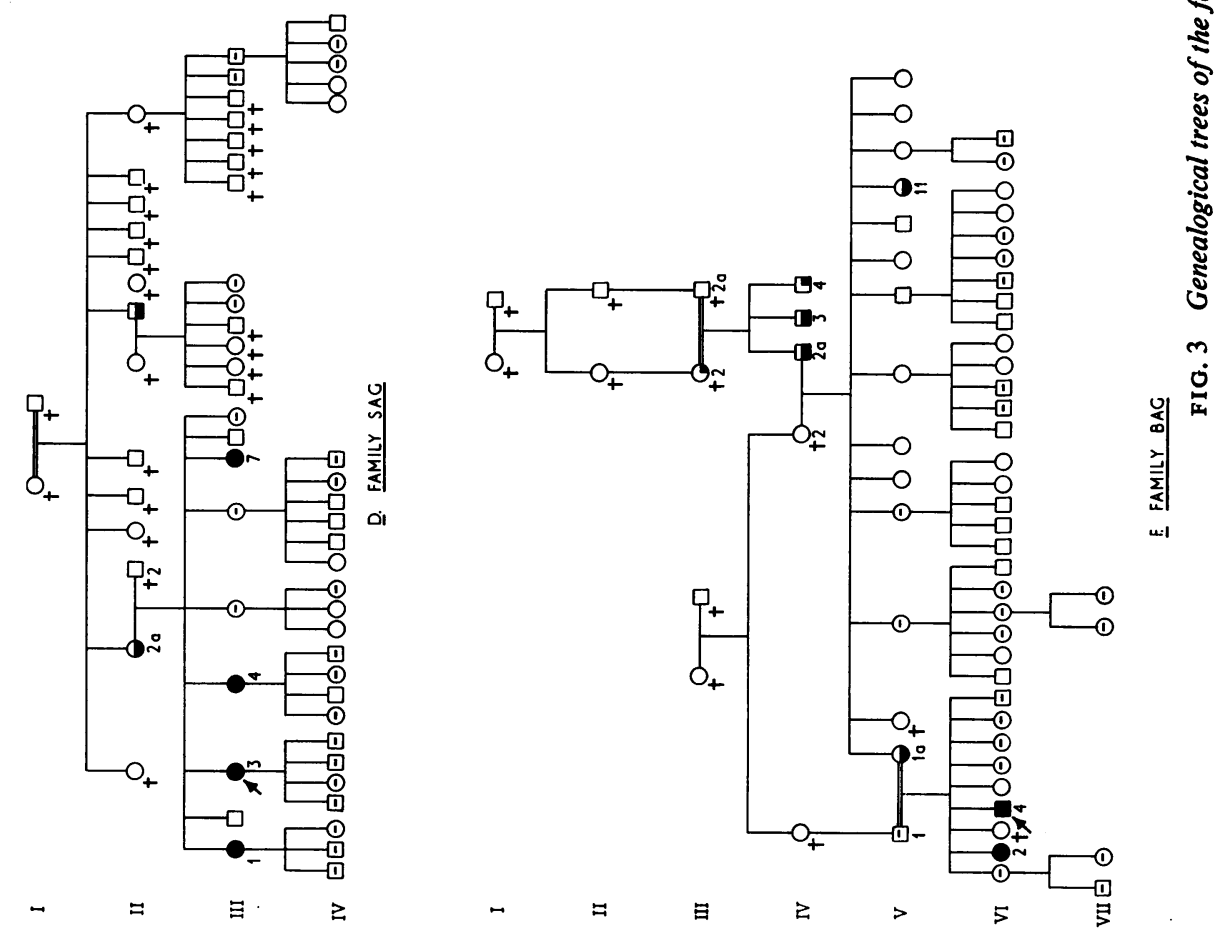
to an isolated archipelago (for historical reasons) and constitute a racial isolate, as shown by the genealogies, the implicit inbreeding should be apparent (Figs 2 and 3). No attempt was made in this study to refine the valuation of inbreeding and its impact in chondrocalcinosis. We limited the study to a direct analysis of sibships which contained at least one affected member. In this way 8 of 10 sibships born from consanguineous marriages were positive. The two exceptions contained young sibs less than 10 years old (which is younger than the age when the disease is manifested on $x$-rays) and one of them was a highly suspected individual with an acute episode of arthritis but with negative $x$-ray studies (Fig. 2B, Family BOG, XIII.8). On the other hand, only thirteen of 35 sibships were positive when no consanguinity was present. However, the proportion of affected sibs was not different between the two sibships.

\section{ANTHROPOLOGICAL STUDIES AND BLOOD GROUPING}

Blood group studies, hair colour, eye colouring, and search for shovel-shape and mesopalatal version of the medial upper incisors, performed on 55 patients with chondrocalcinosis and 33 relatives, are summarized in Tables III and IV. It can be seen that Caucasian genetic features were present in individuals of this population: blood group $B$ in $23, \mathrm{Rh}$ subgroups of $r-r$ type in six, R2-r type in six, and R1-r in thirteen. Grey eyes were present in eight, blue eyes in four, and green eyes in five patients. Light chestnut hair was

Table III Blood grouping studies in 52 patients with chondrocalcinosis born in the Chiloe Islands and in 27 relatives

\begin{tabular}{|c|c|c|}
\hline Blood group & No. of cases & $\%$ \\
\hline $\begin{array}{c}\text { ABO system } \\
\text { O } \\
\text { A } \\
\text { B }\end{array}$ & $\begin{array}{l}43 \\
13 \\
23\end{array}$ & $\begin{array}{l}54 \cdot 43 \\
16 \cdot 46 \\
29 \cdot 11\end{array}$ \\
\hline $\begin{array}{l}\text { MNS system } \\
\text { MM } \\
\text { MN } \\
\text { NN } \\
\text { S } \\
\text { S }\end{array}$ & $\begin{array}{r}37 \\
33 \\
9 \\
28 \\
51\end{array}$ & $\begin{array}{l}46 \cdot 84 \\
41 \cdot 77 \\
11 \cdot 39 \\
35 \cdot 44 \\
64 \cdot 56\end{array}$ \\
\hline $\begin{array}{l}\text { Rh system } \\
\text { D } \\
\text { d }\end{array}$ & $\begin{array}{r}73 \\
6\end{array}$ & $\begin{array}{r}92.41 \\
7.59\end{array}$ \\
\hline $\begin{array}{l}\text { Rh subgroups } \\
\text { Rwl-R2 } \\
\text { R1-R2 } \\
\text { R2-R2 } \\
\text { r-r } \\
\text { R2-r } \\
\text { R1-r }\end{array}$ & $\begin{array}{r}22 \\
21 \\
11 \\
6 \\
6 \\
13\end{array}$ & $\begin{array}{r}27 \cdot 85 \\
26 \cdot 58 \\
13.92 \\
7 \cdot 60 \\
7 \cdot 60 \\
16 \cdot 45\end{array}$ \\
\hline$\underset{\mathbf{K}}{\text { Kell system }}$ & $\begin{array}{r}5 \\
64\end{array}$ & $\begin{array}{r}7.25 \\
92 \cdot 75\end{array}$ \\
\hline
\end{tabular}

Table IV Anthropological markers of genetic value in 55 patients and 33 relatives with chondrocalcinosis born in the Chiloe Islands

$$
\text { No. of cases }
$$

\begin{tabular}{lr}
\hline Eye colour & \\
Black & 3 \\
Dark brown & 50 \\
Light brown & 18 \\
Grey & 8 \\
Blue & 4 \\
Green & 5 \\
Hair colour & \\
Black & 65 \\
Light chestnut & 19
\end{tabular}

Shovel-shape and mesopalatal version of upper medial incisors

$\begin{array}{lr}\text { Positive } & 1 \\ \text { Negative } & 63 \\ \text { Edentulous } & 24\end{array}$

present in nineteen patients. Only one patient showed mesopalatal version and shovel-shape of the medial upper incisor, a feature found in a large portion of the Chilean Indian population (Rothhammer, Lasserre, Blanco, Covarrubias, and Dixon, 1968).

\section{DIETETIC AND MIGRATIONAL SURVEY}

Patients with chondrocalcinosis were born in different parts of the islands; however, most of the cases studied were born around the city of Castro. Twentyfour out of 55 cases have never moved out of the islands, twelve have moved out for periods ranging from 1 to 5 years, and sixteen have lived outside of the islands for more than 25 years. Four patients were born outside of the Islands but their parents and grandparents were born in the Chiloe Islands. Patients who had lived outside of Chiloe have failed to notice any change in their symptoms or in the severity of the course of their disease in relation to their environment.

The dietary qualitative survey disclosed that their food intake consisted of large amounts of potatoes and rice and small amounts of meat, fish, or seafood no more than 3 times a week. Milk and its derivatives were almost absent from their diet.

\section{Discussion}

The results of studying the relative frequency of chondrocalcinosis and other rheumatic diseases in this small selected population of patients born and raised in the Chiloe Islands confirmed our previous findings suggesting a high frequency of chondrocalcinosis there (Reginato and others, 1970). Sixteen $(9.5 \%)$ of 177 rheumatic patients, ages ranging from 20 to 68 years, showed calcification of the articular 
cartilage. This value is significantly higher than the $1 \%$ obtained in a similar study performed in an arthritis clinic in the North of Chile (Carvallo, Aste, and Navarrete, 1970) and also higher than the $0.13 \%$ revealed in another analysis of the relative incidence of rheumatic diseases in central Chile (Lackington, Aviño, and Carrasco, 1972). Information about the prevalence of chondrocalcinosis in the general population is lacking. McCarty and Silcox (1973) have inferred from their pathological data that the prevalence in the general population in the United States is about $3 \%$ at the time of death.

The survey of 1783 articular and spine roentgenograms of patients of all ages showed calcification of the articular cartilage in nineteen cases. This value of $1.6 \%$ is also higher than the $0.42 \%$ obtained from five combined roentgenographic surveys of knee joints reported by Weaver (1942) in which 52 out of 12268 films showed meniscal calcification. Radiographic survey of the knees of elderly people have shown intra-articular calcification in $7 \%$ (Bocher, Mankin, Berk, and Rodnan, 1965), the same value that McCarty, Hogan, Gatter, and Grossman (1966) observed for all types of calcium deposits in the menisci of cadavers. A general population study was difficult to perform in the Chiloe Islands because of the demographic features of this population (Reginato and others, 1970).

The clinical and radiological studies performed in eighty patients with chondrocalcinosis born in the Chiloe Islands also confirmed our findings in Santiago and Punta Arenas (Reginato and others, 1970), showing frequent family aggregation (57 patients in 12 families) of this disease. The most severe form of chondrocalcinosis was seen in patients who noticed their first symptoms around the second and third decade, with heavy articular cartilage and menisci calcification. In a few patients a destructive type of arthritis associated with severe degenerative changes and even bony ankylosis was seen.

Serum calcium, phosphorus, and alkaline phosphatase were within normal limits in 35 patients. No differences were appreciated between these patients and those living outside of the islands (Reginato and others, 1970). Synovial fluid studies of calcium, phosphorus, and alkaline phosphatase in nine of these patients failed to show significant differences from the control group (Table II). This finding is in agreement with those of McCarty, Solomon, Warnock, and Paloyan (1971) and Altman, Muniz, Pita, and Howell (1973) and divergent from the findings of Russel, Bisaz, Fleisch, Currey, Rubenstein, Dietz, Boussina, Micheli, and Fallet (1970) in nonfamilial cases of chondrocalcinosis.

Pyrophosphate concentration in 15 noninflammatory synovial fluids of these patients showed a mean value of $9.31 \pm 5.92 \mu \mathrm{mol} / 1$ pyrophosphate. This mean value is similar to those obtained by Silcox and McCarty (1973) for osteoarthritis $(8 \cdot 40 \pm 1 \cdot 27) \frac{\vec{\partial}}{\widehat{D}}$ and nonfamilial cases of chondrocalcinosis $\left(8 \cdot 86 \pm \frac{5}{3}\right.$ $1.4)$ but with a wider range of variation. No positive correlation was noted between the higher values of pyrophosphate in the synovial fluid and the severity $\vec{F}$ of the joint involvement.

Plasma pyrophosphate concentration was deter-을 mined in 35 patients and twelve normal controls. The $\frac{\overline{\bar{C}}}{\overline{0}}$ values were similar to the control group but higher $\frac{\rho}{\sigma}$ than those reported by Silcox and McCarty (1973)응 with the same technique, using high speed centri-ळ fugation for complete separation of platelets. It was impossible for us under field conditions to attain the ${ }_{-}$ same high centrifugation rates utilized by these $\vec{\omega}$ authors. We attribute our higher values to this shortcoming in our technique.

The migratory survey in these patients has showniw that some of them have been living for a long time outside of the islands; three patients were born andis raised outside of Chiloe. The Chilotes who lived 8 outside of the islands showed no difference in the severity of the course of their disease or their symp-toms when compared with those who had spent all $\subseteq$ their life in the islands. Also, the evidence of the qualitative dietary survey minimized the possibility $\overrightarrow{0}$ that some local environmental factor had influenced $y$ the increased frequency of chondrocalcinosis amog. the Chilotes.

Several simple genetic hypotheses may be cơ sidered in the light of the pedigrees obtained in this study. It appears appropriate to emphasize the higho degree of consanguinity present which is commonly@ seen in recessive inheritance. $40 \%$ of the offspring were $\vec{F}$ found to have chondrocalcinosis when all pedigrees 3 with one diseased parent and the other nonaffected or unknown (probably nonaffected by polyarticular: disease) were pooled (Table V). This is not significantly different from the $50 \%$ expected if all marriages were between recessive homozygous and hetero- $\frac{5}{3}$ zygous individuals. A tendency towards a lower rate is to be expected in marriages between two nonaffected heterozygous parents. Unfortunately, there is no documented case of marriage of nonaffected subjects, 국 which constitutes a lack of critical information to $>$ sustain this hypothesis.

Concerning the existence of a sex-linked recessiven gene, the information is conflicting because there is one pedigree (Fig. 3, Family BAG V, VI) where $N$ affected offspring of both sexes were born from a N diseased woman married to a nonaffected man; we expected only affected men to be born in such a case 0 Criss-cross inheritance seen typically in this kind of inheritance is not documented for lack of information.? On the other hand, the consanguineous pedigree of 0 an affected man with a nonaffected heterozygous woman is expected to have both sexes affected among@ the offspring (Fig. 2, Family BOG XI, XII).

From the available information, an autosomalo 
Table V Summary of mating between one affected parent and the other nonaffected

\begin{tabular}{|c|c|c|c|c|c|}
\hline Mating & $\begin{array}{l}\text { No. of } \\
\text { offspring }\end{array}$ & $\begin{array}{l}\text { No. with } \\
\text { chondrocal- } \\
\text { cinosis }\end{array}$ & $\begin{array}{l}\text { Not } \\
\text { studied }\end{array}$ & $\begin{array}{l}\text { Identity of } \\
\text { chondrocal- } \\
\text { cinosis } \\
\text { offspring }\end{array}$ & $\begin{array}{l}\text { Fraction affected } \\
\text { of all cases studied }\end{array}$ \\
\hline $\begin{array}{l}\text { Nonaffected-affected } \\
\text { BOG XI.8-8a }\end{array}$ & 7 & 4 & - & \multirow{2}{*}{$\begin{array}{c}\text { BOG XII.5, } \\
6,8,9 \\
\text { HUB IV. } 2\end{array}$} & 0.57 \\
\hline $\begin{array}{l}\text { HUB III.7-7a } \\
\text { Affected-nonaffected }\end{array}$ & 5 & 1 & 2 & & 0.33 \\
\hline BAG V.1a-1 & 9 & 2 & 2 & BAG VI.2,4 & $0 \cdot 28$ \\
\hline $\begin{array}{l}\text { BAG IV.2-2a } \\
\text { Affected-unknown }\end{array}$ & 14 & 2 & 10 & BAG V.1a, 11 & 0.50 \\
\hline $\begin{array}{l}\text { GAG XII.38-38a } \\
\text { SAG II.2-2a }\end{array}$ & $\begin{array}{r}10 \\
9\end{array}$ & $\begin{array}{l}1 \\
4\end{array}$ & $\begin{array}{l}7 \\
2\end{array}$ & \multirow{2}{*}{$\begin{array}{l}\text { GAG XII.25 } \\
\text { SAG III.1, } \\
3,4,7 \\
\text { CAB III.4, 5, } \\
11\end{array}$} & $\begin{array}{l}0.33 \\
0.57\end{array}$ \\
\hline CAB I. 1-1a & 11 & 3 & 3 & & $0 \cdot 37$ \\
\hline Totals & 65 & 17 & 26 & & $2.95: 7=0.42$ \\
\hline
\end{tabular}

dominant inheritance cannot be ruled out as there is equality of both sexes affected, no generation is skipped, and the proportion of affected is not significantly different in $50 \%$ of the sibs where one parent has chondrocalcinosis.

Finally, it is tempting to interpret the data with an intermediate or codominant inheritance, where oligoarticular affected subjects $(\mathrm{O})$ are heterozygous and polyarticular (P) are homozygous. However, it is surprising that all affected $P$ descend from $O$ parents. Only one case of affected offspring of a $P$ is seen and this was $O$. The problem here is what we are defining as heterozygous. Since $\mathbf{O}$ phenotypes are usually asymptomatic and calcifications of the knee cartilage of menisci disclosed by $x$-ray studies appear late in life, it is possible that some $\mathrm{O}$ failed to be diagnosed. If so, marriage of an $\mathrm{O}$ with an apparently normal spouse, particularly if consanguineous, may be of two heterozygous persons which could explain the observed pedigrees.

From a genetic viewpoint, we concluded from these results that we have an unusual situation of a genetical and geographical isolate where inbreeding is frequent. This and the actual anthropological data suggest that the genes responsible for the disease in question were of European origin and came with the Conquistadors in the 16th century.

Surveying the pedigrees, it appears that there is inconclusive evidence for formulation of a particular Mendelian theory. However, examining the merits of each hypothesis separately we concluded that (1) the data are better explained by autosomal inheritance. A sex-linked hypothesis conflicts with one pedigree (Fig. 3, Family BAG V, VI). (2) If we do not take into consideration the $O$ and $P$ phenotypes, both recessive and dominant hypotheses are equally consistent with the available information. This interpretation is in agreement with the findings reported by Valsik and others (1963). Recently, Greerards and Van der Korst (1973) have reported a study of a family of Dutch origin with five patients. The survey of 104 relatives disclosed chondrocalcinosis in sixteen of them. Their pedigrees suggested a single autosomal dominant trait although the presence of inbreeding is not mentioned.

Although only a small series of nonfamilial cases of chondrocalcinosis have been reported in Spain (Tomás-Escué, Lience, Casals Jolonch, Torrents, Lagada, and Vintro, 1971), our studies suggest the possibility that this disease was taken to the Chiloe Islands by one or several immigrants of Spanish and Portuguese origin. Further studies in selected regions of Spain and Portugal seem to be necessary to prove this.

We gratefully acknowledge the expert technical advice in genetics given by Dr. William J. Mellman. This study was supported by grants from the University of Chile, the Barsumian Memorial Fund, and partially by USPHS AM 13069

\section{References}

Altman, R. D., Muniz, O. E., Pita, J. C., And Howell, D. S. (1973) Arthr. and Rheum., 16, 171 (Articular chondrocalcinosis: microanalysis of pyro-phosphate in synovial fluid and plasma)

Bachra, B. N., Dauer, A., AND Sobel, A. E. (1958) Clin. Chem., 4, 107 (The complexometric titration of micro and ultramicro quantities of calcium in blood serum, urine and inorganic salt solutions) 
Bocher, J., Mankin, H. J., Berk, R. N., and Rodnan, G. P. (1965) New Engl. J. Med., 272, 1093 (Prevalence of calcified meniscal cartilage in elderly persons)

BodanSKy, A. (1932) J. biol. Chem., 99, 197 (Phosphatase studies. 1. Determination of inorganic phosphate. Beer's law and interfering substances in the Kuttner-Lichtenstein method)

BurR, T. C. H. (1902) ‘A General History of the Burr Family', p. 34. Knickerbocker Press, New York

Carvallo, A. V., Aste, L. S., AND Navarrete, A. B. (1970) Bol. Soc. chil. Reum., 8, 42 (Busqueda de condrocalcinosis articular en Antofagasta)

Catholic Parochial Church (1700-1973) 'Libro de Casamiento de los Espanoles'. Castro, Chiloe

Cavada, F. J. (1934) ‘Apuntes Biograficos de Personas y Familias de Chiloe Insular'. Editorial Nascimento, Santiago, Chile

Fernandez, R. R., Covarrubias, E., Benado, M., Castelli, G., and Lamborot, L. (1966) Biologica, 39, 32 (Microevolucion en las poblaciones humanas chilenas. II Consanguinidad e migracion de los matrimonios del area de Nunoa, Santiago 1850-1960)

Gallardo, P. N. (1953) ‘Anos 1700-1933. Arbol Genealogico de la Familia Gallardo en Chiloe’. Imprenta la Nueva Republica, Santiago, Chile

GeERARDS, J., AND VAN DER KORST, J. K. (1973) Ann. rheum. Dis., 32, 87 (Inheritance of primary articular chondrocalcinosis)

Gomori, G. (1942) J. Lab. clin. Med., 27, 955 (A modification of the colorimetric phosphorus determination for use with the photoelectric colorimeter)

Hollander, J. L., Reginato, A., AND Torralba, T. (1966) Med. Clin. N.Amer., 50, 1281 (Examination of synovial fluid as a diagnostic aid in arthritis)

Kellgren, J. H., Jefrrey, M. R., AND Ball, J. (1963) In 'The Epidemiology of Chronic Rheumatism. Proposed Diagnostic Criteria for Use in Population Studies', p. 32. Blackwell, Oxford

Lackington, C., Aviño, C., and Carrasco, M. (1972) Rev. Med. Chile, 100, 564 (Incidencia relativa de las afecciones reumáticas. Análisis de 1442 casos)

McCarty, D. J., Hogan, J. M., GatTer, R. A., AND Grossman, M. (1966) J. Bone Jt. Surg., 48A, 309 (Studies on pathological calcification in human cartilage: 1 . Prevalence and types of crystal deposits in the menisci of two hundred and fifteen cadavera)

- AND SilcoX, D. C. (1973) Geriatrics, 28, 110 (Gout and pseudogout)

一, Solomon, S. D., Warnock, M. L., AND Paloyan, E. (1971) J. Lab. clin. Med., 78, 216 (Inorganic pyrophosphate concentrations in the synovial fluid of arthritic patients)

Mansilla, L. (1915) 'Relacion Genealogica de Varias Familias de Chiloe'. Editorial San Jose, Santiago, Chile

Parlee, D. E., Freundlich, I. M., AND MCCARTY, D. J., JR. (1967) Amer. J. Roentgenol., 99, 688 (A comparative study of roentgenographic techniques for detection of calcium pyrophosphate dihydrate deposits (pseudogout) in human cartilage)

Reginato, A. M., Valenzuela, F. R., Martinez, V. C., and Passano, G. (1970) Arthr. and Rheum., 13, 197 (Polyarticular and familial chondrocalcinosis)

Rothhammer, F., Lasserre, E., Blanco, R., Covarrubias E., and Dixon M. (1968) Z. Morph. Anthorp., 60, 162 (Microevolution in human Chilean population. IV. Shovel shape, mesial palatal version and other dental traits in Pewenche Indians)

Russel, R. G. G., Bisaz, S., Fleisch, H., Currey, H. L. F., Rubinstein, H. M., Dietz, A. A., Boussina, I., MiCHELI, A., AND FALLET, G. (1970) Lancet, 2, 899 (Inorganic pyrophosphate in plasma, urine and synovial fluid of patients with pyrophosphate arthropathy (chondrocalcinosis or pseudogout))

Schumacher, H. R., AND KulKa, J. P. (1972) New Engl. J. Med., 286, 416 (Needle biopsy of the synovial membrane: experience with the Parker-Pearson technic)

SiLcox, D. C., AND MCCARTY, D. J. (1973) J. clin. Invest., 52, 1863 (Measurement of inorganic pyrophosphate in biological fluids. Elevated levels in some patients with osteoarthritis, pseudogout, acromegaly and uremia)

Singer, J. M., AND Plotz, C. M. (1956) Amer.J. Med., 21, 888 (The latex fixation test: application to the serologic diagnosis of rheumatoid arthritis)

Tomás-Escué, A., Lience, E., Casals Jolonch, J. M., Torrents, A. M., Lagada, J. V., and Vintro, P. (1971) Rev. esp. Reum., 14, 59 (Chondrocalcinosis primitiva. Analisis clinico de 11 casos)

Valsix, J., ANd Zitnan, D. (1966) Acta Rheum. Baln. Pistiniana, 2, 45 (Chondrocalcinosis articularis. B. Genealogica investigation)

- Zrtnan, D., AND SrT'AJ, S. (1963) Ann. rheum. Dis., 22, 153 (Articular chondrocalcinosis: II. Genetic study)

VASQUeZ De ACUnA, I. (1959) 'Garay un linaje portugues en el archipielago de Chiloe', in 'Armerias y Nobilia rio de los Reinos Espanoles', p. 3. Editorial Barcelona, Madrid, Spain

WeAVER, J. B. (1942) J. Bone Jt. Surg., 24, 873 (Calcification and ossification of the menisci)

WeINER, J. S., AND LourIe, J. H. (1969) In 'A Guide to Field Methods', p. 471. Blackwell Scientific Publications, Oxford and Edinburgh 